\title{
ANALISIS PERMINTAAN BERAS DI PROVINSI KALIMANTAN TENGAH
}

\author{
(Analysis of Demand for Rice in the Province of Central Kalimantan)
}

\section{Revi Sunaryati}

Program Studi Agribisnis Fakultas Pertanian Universitas Palangka Raya (UPR)

Kampus UPR : Jl. Yos Sudarso Palangka Raya, Kalimantan Tengah 73111

\begin{abstract}
The purpose of this study is to analyzes the factors that influence the function of demand for rice in the province of Central Kalimantan during the last 20 years, and to determine the elasticity of demand for rice in the province of Central Kalimantan.

Purposively making research sites in The Province of Central Kalimantan. Data collected in the form of secondary data that is demand for rice in the province of Central Kalimantan during the last 20 years with methods of literature arid study the documents that have been provided are obtained from agencies 1-nd private or government institutions that are related to this research The data analysis using Cobb Douglas function.

The result of this study is that static analysis model adjusted $R 2$ value of 0.945 , which means the proportion of the contribution of independent variables to dependent variable amounted to $94.50 \%$, while the remaining $5.50 \%$ is explained by other variables outside the-research such as taste, flavor and consumer Preference. Based on F test variable price of rice, the price of instant noodles, per capita income, population, and education together significantly affected the demand for rice. Based on t-test variable number of people significantly influence demand of rice at the rate of $95 \%$, while per capita income and education variables significantly influence demand for rice at $90 \%$ confidence level. The variables specified in the model and does not affect the demand for rice in the Province of Central Kalimantan is the price of rice and the prices of instant noodles. Elasticity of demand for static model based on price elasticity, price inelastic. Based on cross elasticity, the price of instant noodles do not include substitute goods. Based on the income elasticity, per capita income, is inferior.
\end{abstract}

Keywords : rice, analysis, demand, elasticity

\section{Abstrak}

Tujuan dari penelitian ini adalah untuk menganalisis faktor-faktor yang mempengaruhi fungsi permintaan beras di provinsi Kalimantan Tengah selama 20 tahun terakhir, dan untuk menentukan elastisitas permintaan beras di Provinsi Kalimantan Tengah.

Secara purposif lokasi penelitian dilaksanakan di Provinsi Kalimantan Tengah. Data yang dikumpulkan berupa data sekunder permintaan beras di provinsi Kalimantan Tengah selama 20 tahun terakhir dengan metode studi dokumen literatur lapangan yang telah disediakan dan diperoleh dari lembaga swasta atau lembaga pemerintah yang terkait untuk penelitian ini. Analisis data menggunakan fungsi Cobb Douglas.

Hasil penelitian ini menunjukkan bahwa model analisis statis disesuaikan dengan nilai R2 0,945, yang berarti proporsi kontribusi variabel independen terhadap variabel dependen sebesar 94,50\%, sedangkan sisanya 5,50\% dijelaskan oleh variabel lain di luar penelitian ini seperti rasa, keinginan dan preferensi konsumen. Berdasarkan uji $\mathrm{F}$ harga variabel beras, harga mie instan, pendapatan per kapita, penduduk, dan pendidikan bersama-sama secara signifikan mempengaruhi permintaan beras. Berdasarkan t-test variabel jumlah orang secara signifikan mempengaruhi permintaan beras pada tingkat $95 \%$, sementara variabel pendapatan per kapita dan pendidikan secara signifikan mempengaruhi permintaan beras pada tingkat kepercayaan $90 \%$. Variabel yang ditentukan dalam model tidak mempengaruhi permintaan beras di Provinsi Kalimantan Tengah adalah harga beras dan harga mie instan. Elastisitas permintaan untuk model statis berdasarkan elastisitas harga, menunjukan harga yang tidak elastis. Berdasarkan lintas elastisitas, harga mie instan tidak termasuk barang substitusi. Berdasarkan elastisitas pendapatan, pendapatan per kapita lebih rendah.

Kata kunci : beras, analisis, permintaan, elastisitas 


\section{PENDAHULUAN}

Pangan adalah kebutuhan mendasar yang sangat penting bagi kehidupan setiap insan baik secara fisiologi, psikologis, sosial, maupun antropologis. Pangan selalu terkait dengan upaya manusia untuk mempertahankan hidupnya. Untuk mendukung upaya ini, di samping usaha-usaha untuk terus meningkatkan produksi komoditas pertanian secara ekstensi, dikembangkan program diversifikasi untuk mendapatkan suatu pola konsumsi pangan yang beragam dengan mutu gizi yang seimbang (Seto, 2001).

Pembangunan pangan dan perbaikan gizi adalah suatu upaya pembangunan yang bersifat lintas bidang dan lintas sektor yang saling berkaitan yang ditujukan untuk mencukupi kebutuhan pangan masyarakat secara adil dan merata baik dalam jumlah maupun mutu gizinya. Secara khusus pembangunan pangan adalah upaya pengembangan suatu sistem pangan yang andal, mencakup rangkaian kegiatan saling terkait mulai dari kegiatan produksi, pengolahan, distribusi dan pemasaran sampai tingkat rumah tangga. Adapun upaya perbaikan gizi menekankan pentingnya perbaikan konsumsi pangan rakyat dalam jumlah dan mutu gizi yang cukup dan seimbang sehingga berdampak pada peningkatan status gizi masyarakat (Seto, 2001).

Sesuai UU No 18 Tahun 2012, tentang pangan, pangan adalah kebutuhan dasar manusia yang paling utama dan pemenuhannya bagian dari hak asasi manusia. Oleh karena itu, industri pangan adalah industri yang akan selalu tumbuh, paling tidak mengikuti pertumbuhan penduduk. Tidak heran jika industri pangan, terutama industri berskala kecil bermunculan untuk memenuhi permintaan tersebut. Bahan pokok adalah pangan yang diperuntukkan sebagai makanan utama sehari-hari sesuai dengan potensi sumberdaya dan kearifan lokal.

Sebagai komoditas pangan utama, beras memiliki peran dan posisi yang strategis di masyarakat Indonesia. Permintaan beras cenderung meningkat dari tahun ke tahun seiring dengan pertambahan jumlah penduduk. Pada sisi penawaran, produksi beras berfluktuasi dari musim ke musim, sehingga pada waktu-waktu tertentu terjadi excess supply (musim panen) dan excess demand (paceklik). Kondisi ini yang seringkali menimbulkan ketidakstabilan pasar (Sadono Sukirno, 1994).

Beras adalah kebutuhan utama, dimana semua lapisan masyarakat strata rendah yang lazim disebut keluarga lapisan masyarakat prasejarah, sampai dengan lapisan masyarakat berpenghasilan menengah ke atas, semuanya mengkonsumsi beras, yang membedakannya adalah kuantitas dan kualitas beras yang di konsumsi. Konsumsi pangan di Indonesia dicirikan oleh adanya perbedaan dalam pola konsumsi antar tempat (Sadono Sukirno, 1994).

Salah satu hal penting dalam sistem distribusi beras nasional adalah mengetahui tingkat penyediaan dan permintaan sehingga tidak ada kelangkaan maupun surplus beras di pasaran yang pada akhirnya merugikan masyarakat sebagai konsumen dan petani sebagai produsen beras. Pada tingkat yang 
diinginkan akan tercapai harga beras yang layak dan mampu dijangkau oleh masyarakat dan menguntungkan para petani sebagai produsen. Mengingat peran beras sebagai komoditas pangan utama masyarakat Indonesia, tercapainya kecukupan produksi beras nasional sangat penting sebagai salah satu faktor yang mempengaruhi terwujudnya ketahanan pangan nasional (Soekartawi, 2002).

Apabila dilihat dari segi luas wilayah Provinsi Kalimantan Tengah adalah salah satu Provinsi terbesar setelah Provinsi Kalimantan Timur dan Provinsi Papua. Sedangkan jumlah penduduk Provinsi Kalimantan Tengah pada tahun 2013 sebanyak 2.384.700 jiwa. Mengingat semakin bertambahnya jumlah penduduk dari tahun ke tahun maka permintaan beras juga semakin bertambah seiring dengan bertambahnya jumlah penduduk. Untuk memenuhi permintaan pasar yang semakin besar dan persediaan beras lokal tidak mencukupi maka para produsen cenderung mendatangkan beras dari luar wilayah atau luar pulau seperti Banjarmasin dan pulau Jawa. Permintaan dapat diketahui faktor-faktor yang mempengaruhi permintaan pasar serta mengestimasikan permintaan.

Berdasarkan permasalahan, maka tujuan penelitian ini adalah: 1). menganalisis faktorfaktor yang mempengaruhi fungsi permintaan beras di Provinsi Kalimantan Tengah, 2). menganalisis elastisitas permintaan beras di Provinsi Kalimantan Tengah.

\section{METODOLOGI}

\section{Metode Pengumpulan Data}

Data yang dikumpulkan dalam penelitian ini berupa data sekunder yaitu data permintaan beras di Provinsi Kalimantan Tengah selama 20 tahun (tahun 1994-2013). Data sekunder tersebut diperoleh dari instansi yang terkait dengan penelitian ini seperti: Kantor Dinas Pertanian Provinsi Kalimantan Tengah, Badan

Tabel 1. Rata-rata konsumsi beras perkapita dan pertumbuhan konsumsi perkembangan Provinsi Kalimantan Tengah, Tahun 2004-2013

\begin{tabular}{ccc}
\hline Tahun & Konsumsi Beras (Kg/Kap/Tahun) & Pertumbuhan Perkembangan Konsumsi (\%) \\
\hline 2004 & 103,6 & $-4,72$ \\
2005 & 98,7 & $-0,60$ \\
2006 & 98,1 & 0,71 \\
2007 & 98,8 & 7,38 \\
2008 & 106,1 & $-6,97$ \\
2009 & 98,7 & $-0,40$ \\
2010 & 98,3 & $-2,74$ \\
2011 & 95,6 & $-5,43$ \\
2012 & 90,4 & 10,39 \\
2013 & 99,8 & 10,20 \\
\hline
\end{tabular}

Sumber : BPS Provinsi Kalimantan Tengah, 2013 
Pusat Statistik Provinsi Kalimantan Tengah, serta mempelajari dokumen-dokumen yang telah tersedia, jenis data yang dikumpulkan adalah berupa data kuantitatif antara lain meliputi data (a) permintaan beras (ton); (b) harga beras $(\mathrm{Rp} / \mathrm{Kg})$; (c) harga mie instan (Rp/bks); (d) pendapatan penduduk (Rp/Kapita); (e) Jumlah Penduduk (jiwa); dan pendidikan.

\section{Analisis Pengolahan Data}

Alat analisis yang digunakan untuk mengolah data adalah analisis regresi umum dengan menggunakan paket program SPSS.

1. Untuk menjawab tujuan pertama yaitu untuk mengetahui fungsi permintaan beras di Provinsi Kalimantan Tengah dianalisis dengan menggunakan model Cobb Douglas karena dalam analisis ini tidak menghitung nilai keofisien regresi/elastisitas, tidak mempunyai batasan nilai maksimumnya.

Dengan persamaan sebagai berikut.:

$$
\mathbf{Y}=\mathbf{b}_{0} \mathbf{X}_{1}{ }^{\mathrm{b} 1} \cdot \mathbf{X}_{2}{ }^{\mathrm{b} 2} \cdot \mathbf{X}_{3}{ }^{\mathrm{b} 3} \cdot \mathbf{X}_{4}{ }^{\mathrm{b} 4} \cdot \mathrm{X}_{5}{ }^{\mathrm{b} 5} \mathrm{e}
$$

Keterangan:

Y : Jumlah Permintaan beras $(\mathrm{Kg})$

bo : Intercep/titik potong

$b^{1-4}$ : Koefisien Regresi

$\mathrm{X}_{1}$ : Harga beras $(\mathrm{Rp} / \mathrm{Kg})$

$\mathrm{X}_{2}$ : Harga mie instan (Rp/Bks)

$\mathrm{X}_{3}$ : Pendapatan penduduk (Rp/Kapita)

$\mathrm{X}_{4}:$ Jumlah penduduk (Jiwa)

$\mathrm{X}_{5}$ : Pendidikan

e : Eror

Kemudian ditransfer ke dalam bentuk logaritma natural untuk memudahkan dalam analisis regresi linear, sehingga model tersebut mempunyai persamaan yaitu :

$$
\begin{aligned}
\operatorname{Ln} Y= & \operatorname{Ln} b_{0}+b_{1} \operatorname{Ln} X_{1}+b_{2} \operatorname{Ln} X_{2}+b_{3} \\
& \operatorname{Ln} X_{3}+b_{4} \operatorname{Ln} X_{4}+b_{5} \operatorname{Ln} X_{5}+e
\end{aligned}
$$

Untuk mengetahui berapa besar pengaruh variabel bebas $(\mathrm{X})$ terhadap variabel terikat (Y) yang dalam studi ini adalah jumlah permintaan beras, dapat dilihat melalui besarnya koefesien determinasi $\left(\mathrm{R}^{2}\right)$. Nilai $\mathrm{R}^{2}$ berkisar antara $0(0 \%)$ dan $1(100 \%)$ nilai $\mathrm{R}^{2}$ yang mendekati 1 menunjukkan bahwa hasil perhitungan koefesien tersebut makin baik, karena variabel yang dianggap mempengaruhi variabel terikat (Y) bisa menerangkan lebih banyak perubahanperubahan dari Y tersebut.

Uji $F$ digunakan untuk mengetahui tingkat keeratan hubungan secara bersama-sama antara berpengaruh terhadap jumlah permintaan beras pada tingkat kesalahan $\alpha=$ $1 \%, 5 \%$, atau $10 \%$.

Jika $\mathrm{F}_{\text {hitung }}>\mathrm{F}_{\text {tabel }}$ maka Ho ditolak dan $\mathrm{Ha}$ diterima yang berarti bahwa variabel independent $\left(\mathrm{X}_{1}\right)$ berpengaruh secara signifikan terhadap variabel dependen $(\mathrm{Y})$. jika $\mathrm{F}_{\text {hitung }}<\mathrm{F}_{\text {tabel }}$ maka Ho diterima dan Ha ditolak yang berarti bahwa variabel independent $\left(\mathrm{X}_{1}\right)$ tidak berpengaruh secara signifikan terhadap variabel dependent $(\mathrm{Y})$. Rumus perbandingan antara $\mathrm{F}_{\text {hitung }}$ dengan $\mathrm{F}_{\text {tabel }}$ yaitu :

$$
\mathrm{F}_{- \text {hitung }}=\frac{\mathrm{R}^{2} / \mathrm{K}}{\left(1-\mathrm{R}^{2}\right)(\mathrm{n}-\mathrm{k}-1)}
$$

$\mathrm{F}_{\text {tabel }}=(\mathrm{K}: \mathrm{n}-\mathrm{k}-1)$

Keterangan :

$\mathrm{R}^{2}=$ Koefisien determinasi

$\mathrm{K}=$ Derajat bebas

$\mathrm{k}=$ Jumlah variabel bebas

$\mathrm{n}=$ Jumlah observasi 
Sedangkan untuk menguji keberartian koefisien regresi yang sekaligus koefisien elastisitas dari permintaan beras dengan hipotesis :

$$
\begin{aligned}
& \text { Ho : bi }=0 \\
& \text { Ha }: b i \neq 0
\end{aligned}
$$

Cara pengambilan keputusan : 1). jika $\mathrm{T}_{\text {hitung }}$ $>\mathrm{T}_{\text {tabel }}$ maka Ho ditolak dan Ha diterima yang berarti bahwa variabel independent $\left(\mathrm{X}_{1}\right)$ berpengaruh secara signifikan terhadap variabel dependent (Y), 2). jika $T_{\text {hitung }}<T_{\text {tabel }}$ maka Ho diterima Ha ditolak yang berarti bahwa variabel independent $\left(\mathrm{X}_{1}\right)$ tidak berpengaruh secara signifikan terhadap variabel dependent (Y).

2. Untuk menjawab tujuan penelitian yang kedua, yaitu menganalisis elastisitas permintaan beras di Provinsi Kalimantan Tengah, dilakukan dengan mengetahui nilai koefisien regresi yang sekaligus koefisien elastisitas permintaan beras.

\section{HASIL DAN PEMBAHASAN}

\section{Perkembangan Permintaan Beras}

Perkembangan permintaan beras di Provinsi Kalimantan Tengah dapat dilihat pada Tabel 2. Berdasarkan Tabel 2 dapat dilihat bahwa perkembangan permintaan beras di Provinsi Kalimantan Tengah setiap tahunnya mengalami peningkatan. Angka peningkatan permintaan beras di Provinsi Kalimantan Tengah terdapat pada tahun 2013 yaitu sebesar $44,42 \%$ dan penurunan terendah terjadi pada tahun 2001 yaitu sebesar -1,23\%.

\section{Analisis Faktor-Faktor yang Mempengaruhi Permintaan Beras}

Berdasarkan tujuan penelitian yang pertama yaitu menganalisis faktor-faktor yang mempengaruhi permintaan beras di Provinsi Kalimantan Tengah, maka untuk menjawab tujuan tersebut dapat digunakan alat analisis model Cobb-Douglas. Dalam pengelolahan data tersebut digunakan alat bantu komputer dengan program SPSS. Dengan bantuan program analisis data, maka jumlah permintaan beras $(\mathrm{Y})$, harga beras $\left(\mathrm{X}_{1}\right)$, harga mie instan $\left(\mathrm{X}_{2}\right)$, pendapatan perkapita $\left(\mathrm{X}_{3}\right)$, jumlah penduduk $\left(\mathrm{X}_{4}\right)$, dan pendidikan $\left(\mathrm{X}_{5}\right)$ diperoleh dari model Cobb-Douglas menghasilkan persamaan:

$\mathrm{Y}=-6,039 \mathrm{X}_{1}{ }^{0,119} \mathrm{X}_{2}{ }^{0,061} \mathrm{X}_{3}{ }^{-0,245} \mathrm{X}_{4}{ }^{0,902} \mathrm{X}_{5}{ }^{0.442}$

Untuk memudahkan perhitungan persamaan di atas, maka persamaan ini di ubah menjadi logaritma natural (Ln) yang menghasilkan persamaan regresi :

$\mathrm{LnY}=-6,039+0,119 \operatorname{LnX} \mathrm{X}_{1}+0,061 \mathrm{LnX}_{2}+$ $-0,245 \operatorname{LnX}_{3}+0,902 \operatorname{LnX}_{4}+0,442 \operatorname{LnX}_{5}$

\section{a. $\mathbf{U j i} \mathbf{R}^{2}$}

Nilai koefisien determinasi $\left(\mathrm{R}^{2}\right)$ menunjukkan seberapa besar sumbangan variabel-variabel bebas secara bersama-sama terhadap variabel tidak bebasnya. Berdasarkan hasil dari analisis diperoleh nilai $\mathrm{R}^{2}$ sebesar 0,945. Hal ini menunjukkan bahwa 94,50\% permintaan beras di Provinsi Kalimantan Tengah dapat dijelaskan oleh variabel bebas yang digunakan dalam model yaitu harga beras, harga mie instan, pendapatan perkapita, jumlah penduduk, dan pendidikan. Sedangkan sisanya sebesar 
Tabel 2. Perkembangan permintaan beras di Provinsi Kalimantan Tengah, Tahun 2004 -2013

\begin{tabular}{ccc}
\hline Tahun & Permintaan Beras (Ton) & Persentase Kenaikan $(\boldsymbol{\%})$ \\
\hline 2004 & 233,022 & 2,30 \\
2005 & 238,458 & 2,33 \\
2006 & 244,020 & 2,33 \\
2007 & 249,309 & 2,16 \\
2008 & 259,694 & 4,16 \\
2009 & 265,883 & 2,38 \\
2010 & 269,345 & 1,30 \\
2011 & 273,856 & 1,67 \\
2012 & 278,061 & 1,53 \\
2013 & 290,361 & 4,42 \\
\hline
\end{tabular}

Sumber : Dinas Pertanian Provinsi Kalimantan Tengah, 2014

$5,50 \%$ dijelaskan oleh variabel lain di luar model, misalnya: selera konsumen, cita rasa, preferensi konsumen dll.

\section{b. Uji F}

Uji $\mathrm{F}$ digunakan untuk mengetahui apakah variabel bebas yang diteliti secara bersamasama berpengaruh nyata terhadap permintaan beras di Provinsi Kalimantan Tengah. Hasil analisis uji $\mathrm{F}$ dapat dilihat pada Tabel 3.

Berdasarkan analisis uji $\mathrm{F}$ yang dilakukan dapat diketahui bahwa nilai signifikasi sebesar 0,000 dan lebih kecil dari $\alpha=0,01$. Hal ini menunjukkan bahwa variabelvariabel bebas yang diamati yaitu harga beras, mie instan, pendapatan perkapita, jumlah penduduk, dan pendidikan secara bersama-sama berpengaruh nyata terhadap permintaan beras di Provinsi Kalimantan Tengah.

\section{c. $\mathbf{U j i}-\mathbf{t}$}

Uji- t digunakan untuk mengetahui pengaruh variabel bebas yang diteliti secara individual terhadap permintaan beras di Provinsi Kalimantan Tengah. Hasil analisis uji- $t$ dapat dilihat pada Tabel 4.

Tabel 4 menunjukkan bahwa pendapatan perkapita dan pendidikan berpengaruh nyata terhadap permintaan beras di Provinsi Kalimantan Tengah pada tingkat kepercayaan 90\%, sedangkan variabel jumlah penduduk berpengaruh nyata pada tingkat kepercayaan 95\%. Selanjutnya, variabel harga beras dan mie instan tidak berpengaruh nyata terhadap permintaan beras di Provinsi Kalimantan Tengah.

Penjelasan hasil analisis regresi dari masing-masing variabel dapat dijelaskan sebagai berikut: 
Tabel 3. Hasil analisis varian variabel-variabel yang berpengaruh terhadap permintaan beras di Provinsi Kalimantan Tengah

\begin{tabular}{lccccc}
\hline \multicolumn{1}{c}{ Model } & Sum of Squares & df & Mean Square & F & Sig. \\
\hline Regression & .134 & 5 & .027 & 23.163 & $.000^{\mathrm{a}}$ \\
Residual & .016 & 14 & .001 & & \\
Total & .150 & 19 & & & \\
\hline
\end{tabular}

Sumber : Data Sekunder yang diolah, 2015

$* * *$ : signifikasi pada tingkat kepercayaan $99 \%$

Tabel 4. Hasil Uji-t masing-masing variabel bebas

\begin{tabular}{lccc}
\hline \multicolumn{1}{c}{ Variabel } & Koefisien Regresi & Nilai t Hitung & Signifikasi \\
\hline Harga Beras $\left(\mathrm{X}_{1}\right)$ & 0,119 & 1,498 & $0,156 \mathrm{~ns}$ \\
Harga Mie Instan $\left(\mathrm{X}_{2}\right)$ & 0,061 & 0,545 & $0,595 \mathrm{~ns}$ \\
Pendapatan Perkapita $\left(\mathrm{X}_{3}\right)$ & $-0,245$ & $-1,920$ & $0,075 *$ \\
Jumlah Penduduk $\left(\mathrm{X}_{4}\right)$ & 0,902 & 2,428 & $0,029 * *$ \\
Pendidikan $\left(\mathrm{X}_{5}\right)$ & 0,442 & 1,814 & $0,091 *$ \\
\hline
\end{tabular}

Sumber : Data Sekunder yang diolah, 2015

Keterangan :

$* * *$ : signifikasi pada tingkat kepercayaan $99 \% ; \mathrm{t}_{\text {tabel }}=2,976$

$* *$ : signifikasi pada tingkat kepercayaan $95 \% ; \mathrm{t}_{\text {tabel }}=2,144$

* : signifikasi pada tingkat kepercayaan $90 \% ; \mathrm{t}_{\text {tabel }}=1,761$

ns : tidak signifikan

\section{Harga Beras $\left(\mathbf{X}_{1}\right)$}

Hasil analisis menunjukkan bahwa koefisien regresi yang bertanda positif, artinya bila harga beras naik maka jumlah beras yang diminta akan naik. Meskipun harga beras bertanda positif, tetapi pengaruhnya tidak signifikan terhadap permintaan beras di Provinsi Kalimantan Tengah.

\section{Pendapatan Perkapita (X3)}

Pendapatan adalah faktor yang penting dalam menentukan variasi permintaan terhadap berbagai jenis barang karena besar kecilnya pendapatan dapat menggambarkan daya beli konsumen. Bila terjadi perubahan dalam pendapatan maka akan menimbulkan perubahan dalam mengkonsumsi berbagai jenis barang.
Berdasarkan hasil analisis uji-t diketahui bahwa variabel pendapatan penduduk berpengaruh signifikan terhadap permintaan beras. Nilai elastisitas negatif menunjukkan bahwa pendapatan penduduk berbanding terbalik dengan jumlah permintaan beras di Provinsi Kalimantan Tengah.

\section{SIMPULAN DAN SARAN}

\section{Simpulan}

Penelitian mengenai permintaan beras di Provinsi Kalimantan Tengah menghasilkan kesimpulan sebagai berikut :

1. Permintaan beras di Provinsi Kalimantan Tengah pada tahun 2013 sebesar 290,361 
ton, dengan rata-rata peningkatan sebesar $2,21 \%$ pertahun dengan jumlah penduduk sebesar 2.384.700 jiwa.

2. Faktor-faktor yang berpengaruh nyata terhadap permintaan beras di Provinsi Kalimantan Tengah adalah (a) pendapatan perkapita berkolerasi negative serta (b) jumlah penduduk dan (c) pendidikan berkolerasi positif. Faktor harga beras dan harga mie instan (sebagai barang substitusi), ternyata tidak berpengaruh nyata terhadap permintaan beras di Provinsi Kalimantan Tengah.

3. a). Elastisitas pendapatan terhadap permintaan beras adalah sebesar -0,245 yang berarti bahwa setiap terjadi kenaikan $1 \%$ akan menurunkan sebesar 0,245. b). Elastisitas jumlah penduduk terhadap permintaan beras adalah sebesar 0,902 yang berarti setiap terjadi kenaikan $1 \%$ akan menurunkan sebesar 0,902. c). Elastisitas pendidikan terhadap permintaan beras adalah sebesar 0,442 yang berarti setiap terjadi kenaikan $1 \%$ akan menurunkan sebesar 0,442 .

\section{Saran}

Mengingat beras adalah bahan makanan pokok permintaan beras tiap tahunnya meningkat. Untuk itu perlu adanya upaya untuk menjaga ketersediaan beras agar kebutuhan akan beras dapat selalu terpenuhi. Dalam upaya menjaga dan memenuhi kebutuhan beras perlu diperhatikan adalah menjaga proses distribusi beras agar permintaan beras di Provinsi Kaliamantan Tengah terpenuhi, selain distribusi upaya menjaga dan memenuhi perlu diperhatikan bahwa beras dipengaruhi oleh pendapatan perkapita, jumlah penduduk dan pendidikan. Sedangkan pengaruh yang paling besar mempengaruhi permintaan beras adalah jumlah penduduk diikuti pendapatan perkapita dan pendidikan di Provinsi Kalimantan Tengah.

\section{DAFTAR PUSTAKA}

Badan Pusat Statistika Provinsi Kalimantan Tengah. 2013. Kalimantan Tengah Dalam Angka 2014. Palangka Raya.

Badan Pusat Statistika Provinsi Kalimantan Tengah. 2014. Kalimantan Tengah Dalam Angka 2014. Palangka Raya.

Budiono.1990. Pengantar Ekonomi Mikro. BPFE Yogyakarta. Yogyakarta.

Dinas Perindustrian dan Perdagangan. 2013. Standar Perkapita Penduduk Persamaan Bulan. Kalimantan Tengah.

Dinas Pertanian. 2014. Permintaan Beras di Provinsi Kalimantan Tengah. Kalimantan Tengah

Febriani, Intan.2011. Analisis Efisiensi Tataniaga Terung di Kecamatan Kuranji Kota Padang. Skripsi Pertanian. Universitas Andalas.

Huniarto. 1993. Analisis Permintaan Telor Unggas di Kota Palangka Raya. FP UNPAR. Palangka Raya.

Kadariah. 1994. Teori Ekonomi Mikro. Edisi Revisi. FP LPFE UI. Jakarta.

Karim. 2001. Analisis Permintaan Gula Pasir di Kota Palangka Raya. FP UNPAR. Palangka Raya.

Kirana, Nila 2003. Pemasaran Hasil Produksi Bawang Merah. Dikutip Dari Harian Kompas 2003. Jawa Timur. 
Mariyam. 2003. Analisis Permintaan Minyak Goreng di Kota Palangka Raya. Skripsi. FP UNPAR. Palangka Raya.

Paul. A.S dan William. D.N. 1992. Pengantar Ekonomi Mikro. BPFE Yogyakarta. Yogyakarta.

Rahardja Prathama. 2006. Teori Ekonomi Mikro. Edisi III. LPFE UI. Jakarta.

Sabran. 2000. Analisis Permintaan Beras di Kota Palangka Raya. FP UNPAR.Palangka Raya.

Sadono Sukirno. 1994. Pengantar Teori Ekonomi Mikro. PT. Raja Grafindo Persada Jakarta.

Sadono Sukirno. 1985. Ekonomi Pembangunan. Lembaga Penerbit Fakultas Ekonomi. Edisi Revisi I Universitas Indonesia Jakarta.

Seto, Sagung. 2001. Pangan dan Gizi. Institut Pertanian Bogor. Bogor .

Soekartawi. 1994. Pembangunan Pertanian. Edisi I. PT. Rajagrafindo Persada. Jakarta.

Soekartawi. 2002. Prinsip Dasar Manajemen Hasil-Hasil Pertanian : Teori dan Aplikasinya. Edisi I. Cetakan 3. PT. Rajagrafindo Persada. Jakarta.

Sudarsono. 1998. Pengantar Ekonomi Mikro. LP3es. Jakarta.

Suparmoko. 1990. Pengantar Ekonomi Mikro. BPFE Yogyakarta. Yogyakarta. 